Nordisk Judaistik $\bullet$ Scandinavian Jewish Studies

Vol. 26, No. I-2, 2008, I33-156

\title{
BARMHÄRTIGA SVENSKAR OCH TACKSAMMA FLYKTINGAR \\ Ett beredskapssjukhus \\ sommaren 1945 i svensk press
}

\author{
Lena Roos \\ Högskolan i Gävle
}

\begin{abstract}
A в S TRACT In June of 1945 Sweden agreed to receive 10 ooo former prisoners of German concentration camps for medical care. Approximately I200 of these were to be assigned to a temporary hospital in the small Swedish town of Sigtuna. A study of how a selection of Swedish daily papers describe this event shows that the reporters tend to focus more on the Swedish hospital staff than on the refugees. The refugees are merely portrayed as the recipients of Sweden's humanitarian assistance. In these articles, the refugees have no past and no future. Their role is merely to express their gratitude and to recover, thereby testifying to the efficacy of the Swedish hospital. Life in the hospital in Sigtuna is described as close to paradise. That many of the patients were in such poor condition so that they died shortly after their arrival in Sigtuna is rarely mentioned. These tendencies in the articles about the Sigtuna hospital can be connected to Sweden's postwar need to redeem its tarnished reputation as a neutral country by portraying itself in public debate as the champion of a humanitarian tradition. It can also be analysed on the basis of what other studies have shown of how Swedish reporters of the r 1980 os and I990s constructed an idealistic picture of Sweden and the Swedes by describing immigrants and refugees as the essential Other.
\end{abstract}

Den Io juni 1945 meddelade Svenska Dagbladet att Sverige skulle ta emot en grupp på Io ooo för detta koncentrationslägerfångar varav I 200 skulle placeras på ett beredskapssjukhus i den lilla staden Sigtuna. ${ }^{1}$ Denna artikel ska handla om hur flyktingmottagandet i Sigtuna skildrades i den samtida pressen. ${ }^{2}$ 
Min undersökning är i första hand baserad på 29 artiklar som publicerades juni-oktober 1945 . $^{3}$ Artiklarna kommer företrädelsevis från dagstidningar, både rikstäckande publikationer som Svenska Dagbladet, Dagens Nyheter, Aftonbladet och Morgontidningen, och lokaltidningar som Upsala Nya Tidning, Örebrokuriren och Vestmanlands Läns Tidning. Urvalet av artiklar är baserad på den samling pressklipp om denna händelse som finns i Sigtunastiftelsens klipparkiv. Detta urval är säkerligen inte heltäckande, men med tanke på att arkivet hade funnits sedan I9I7 och hade ambitionen att spegla ett representativt urval av den svenska pressen så finns det anledning att anta att arkivets samling artiklar om denna händelse ger en bra bild av hur den skildrades i svensk press. Klipparkivets seriositet, professionalitet och nästan 30-åriga erfarenhet gör att jag bedömer att risken är liten att arkivets samling av artiklar skulle utgöra ett tendentiöst urval, även om Sigtunastiftelsen självt var en av huvudaktörerna i mottagandet genom att man upplät sina lokaler.

För att få perspektiv på detta samtida pressmaterial har jag även jämfört skildringen av mottagandet i artiklarna med den bild man får om man läser de bevarande medicinska journalerna från beredskapssjukhuset. ${ }^{4}$ Eftersom detta material innehåller känsliga personuppgifter och fortfarande är sekretessbelagt så kommer jag inte att hänvisa till enskilda journaler eller akter utan snarare försöka ge en samlad bild av återkommande element i materialet.

Jag kommer även att relatera det samtida pressmaterialet till tidigare forskning, t. ex. Mikael Byströms nyutkomna avhandling i historia En broder, gäst och parasit. Uppfattningar och föreställningar om utlänningar, fyktingar och flyktingpolitik i svensk offentlig debatt 1942-1947 ${ }^{5}$ och Ylva Brunes avhandling i journalistik Nyheter frän gränsen. Tre studier i journalistik om "invandrare», flyktingar och rasistiskt våld. ${ }^{6}$ Brunes avhandling behandlar visserligen huvudsakligen pressmaterial från 1980-I990-tal, men de teoretiska resonemangen är utan tvekan överförbara på detta material från 1945 .

\section{Händelseförloppet}

I juni I945 etablerades ett beredskapssjukhus i Sigtuna för att ta emot flyktingar från koncentrationslägret Bergen-Belsen. Mottagandet administrerades av Civilförsvarsstyrelsen. Denna grupp var en del 
av en grupp före detta koncentrationslägerfångar som Sverige hade lovat ta emot efter en förfrågan från UNRRA (United Nations Relief and Rehabilitation Administration), en flyktingorganisation som skapats 1943 av de allierade för att ge humanitär hjälp. Flyktingarna kom från olika länder men ungefär hälften var polacker. Den ursprungliga tanken var att de skulle få medicinsk vård i Sverige och sedan återvända till sina hemländer. ${ }^{7}$ Denna grupp var i mycket sämre fysiskt skick än den grupp som anlänt tidigare samma år med de "Vita bussarna» och därmed i stort behov av vård. ${ }^{8}$

Planerna var att ca I200 patienter skulle tas emot i Sigtuna men i realiteten blev det mycket färre. I de medicinska journalerna från beredskapssjukhuset förekommer knappt 400 patienter. Majoriteten av flyktingarna var unga judiska kvinnor, de flesta i 20 -års åldern. Många av dem var sjuka i sjukdomar de hade ådragit sig i Bergen-Belsen eller i andra koncentrationsläger där de hade vistats tidigare. Bland de vanligaste åkommorna var tbc och lungsäcksinflammation. Många led också av sviter efter tyfus. Ett flertal patienter får helt enkelt diagnosen »konvalescent» i sina journaler, dvs var i första hand i behov av vila och god omvårdnad för att tillfriskna och hämta krafter.

Beredskapssjukhuset inrymdes i fyra skolor i Sigtuna:

- Sigtunastiftelsen som var en folkhögskola, grundad av Manfred Björkquist (sedermera biskop i Stockholm)

- Svenska kyrkans lekmannaskola, diakonistyrelsens anstalt för utbildning av frivilliga för kyrkligt församlingsarbete

- Sigtunaskolan, ett internat för pojkar

- Humanistiska läroverket, en skola för både pojkar och flickor ${ }^{9}$ Redan under kriget hade förberedelser gjorts för att snabbt kunna bygga upp ett beredskapssjukhus i Sigtuna för den händelse att patienter från Stockholms sjukhus skyndsamt skulle behöva evakueras. ${ }^{10}$ En stor stab av vårdpersonal anställdes för att ta hand om patienterna från koncentrationslägren. ${ }^{11}$ Många av patienterna blev bara kvar på Sigtunasjukhuset under ett par månader och flyttades sedan vidare till andra sjukhus, konvalescentläger eller »utlänningsläger». En pådrivande faktor för att patienterna inte skulle bli kvar i Sigtuna efter sommaren var säkerligen de olika skolornas önskemål om att kunna starta sina kurser som planerat i början av höstterminen. ${ }^{12}$ Att döma av de medicinska journalerna så verkar det som om de sista patienterna lämnade Sigtunasjukhuset i december 1945 . 


\section{Smittorisk och skolelever}

Direkt när tidningarna börjar skriva om beredskapssjukhuset i Sigtuna framförs farhågor om hur detta kan drabba lokalbefolkningen. Oron som uttrycks berör framförallt två områden: att flyktingarnas närvaro ska innebära att Sigtunaborna utsätts för smittsamma sjukdomar, och att eleverna på de fyra skolorna vars lokaler tagits i anspråk ska drabbas genom att kurser ställs in.

När det gäller smittorisken så förefaller ledande personer i flyktingmottagningen ha varit angelägna om att lugna befolkningen och tidningarna fyller utan tvivel en viktig funktion i att sprida dessa lugnande budskap: Patienterna ska både "avlusas» och undersökas innan de kommer till Sigtuna. ${ }^{13}$ Man ska ordna rening av avloppsvattnet från sjukhuset så att inte något badförbud ska behöva utfärdas. Redan vid ankomsten till Stockholm ska man sortera ut de patienter som lider av smittsamma tarmsjukdomar. Överläkaren för beredskapssjukhuset, Dr. Olof Odén, har också meddelat att »efter ytterligare undersökningar i Sigtuna avpoletteras efter hand sjuka med tuberkulos eller andra smittosamma åkommor för förläggning på annan plats.» ${ }^{14}$ I en annan artikel en dryg vecka senare anger Dr. Odén att tuberkulösa och smittsamma fall ska »utgallras» redan när flyktingarna ankommer till Sverige, i Helsingborg. I Sigtuna ska man ta emot konvalescenter och kirurgiska fall. ${ }^{15}$ Inte i någon artikel förekommer det att någon skribent ifrågasätter detta budskap från Dr. Odén. En analys av de medicinska journalerna visar dock att Odén var överdrivet optimistisk. Tbc är en vanlig diagnos bland patienterna i Sigtuna, och enligt journalerna var tbc också en vanlig bidragande dödsorsak bland de patienter som dog på beredskapssjukhuset. Senare artiklar från sommaren 1945 berättar även om de många tbc-fallen på Sigtunasjukhuset. ${ }^{16} \mathrm{I}$ en artikel om mottagandet som publicerades 50 år senare berättar en kvinna som tjänstgjorde som »hjälpsköterska» på sjukhuset att även två av sköterskorna blev smittade av tbc. ${ }^{17}$ Men här verkar myndigheter och media ha samverkat för att inte oroa ortsbefolkningen.

För att minska smittorisken i Sigtuna så inhägnas sjukhusområdet med taggtråd och vaktas av beväpnade vakter. ${ }^{18} \mathrm{Om}$ någon obehörig dristar sig in på sjukhusområdet så ska även denne sättas i tre veckors karantän. ${ }^{19}$ Det framgår inte av pressmaterialet hur länge karantänen 
varade men dock att reportrarna under bevakning fick möjlighet att hälsa på några av patienterna redan första veckan och även därefter $\mathrm{i}$ någon mån fick röra sig inne på sjukhuset. ${ }^{20}$

När det gäller det andra orosmomentet, den ordinarie verksamheten på de fyra skolorna, så ställs flyktingarnas behov mot elevernas och Sigtunabornas. ${ }^{21}$ Dagens Nyheter skriver dagen efter att Svenska Dagbladet först har tillkännagivit nyheten om beredskapssjukhuset:

Ett dråpslag har i dagarna riktats mot Sigtunaskolan, som av Civilförsvarsstyrelsen fått ett föreläggande att utrymma sina lokaler med mycket kort varsel. Enligt vad Dagens Nyheter erfarit från Sigtuna kommer detta att medföra mycket svåra konsekvenser för skolans vidkommande, enär en mängd kontraherade kurser, däribland ferieundervisningen, och diverse andra engagemang måste slopas. Såväl skolan som de enskilda funktionärerna kommer att göra ekonomiska förluster. ${ }^{22}$

Dagen efter denna artikel publicerar Stockholmstidningen en insändare med rubriken »Var det ofrånkomligt?» där skribenten påpekar vilken svår situation detta har skapat för Sigtuna och för den kulturella verksamhet som bedrivs där. Skribenten konstaterar dock att "Det ligger i öppen dag och behöver inte närmare utvecklas, att det krigsskonade Sverige skall göra allt vad i dess förmåga står för att hjälpa de olyckliga som drabbats av kriget», men kritiserar icke desto mindre hur hela mottagandet har organiserats och frågar sig om denna »drastiska, utan varning företagna åtgärd» verkligen var ofrånkomlig. ${ }^{23}$ I de tidiga artiklarna där farhågorna för lokalbefolkningen uttrycks, balanseras dock dessa inte sällan med uttalanden om att Sverige, såsom »ett från kriget förskonat land» har en plikt att göra en insats för flyktingarna, även om det innebär olägenheter för svenskarna. ${ }^{24}$ Stockholmsbiskopen Manfred Björkquist, grundare av Sigtunastiftelsen och boende i Sigtuna, intervjuas i en av artiklarna och lyfter då fram behovet av att harmonisera plikten att hjälpa flyktingar med den egna befolkningens behov:

Icke så att biskopen skulle vilja stänga Sverige för denna mänskliga gärning. Han menar alldeles tvärt om i det stycket. Sverige som sluppit kriget har plikt att tjäna och hjälpa olyckliga människor - det är Stockholmsbispens mening. Men han säger desslikes att denna vår strävan så mycket som möjligt 
bör läggas så, att den icke inkräktar på våra egna möjligheter att fostra och dana vårt eget folk. ${ }^{25}$

\section{॥... bra nära himlen»}

Mycket utrymme i artiklarna ägnas åt hur flyktingarna måste uppleva att de har kommit nära himlen när de kommer till sjukhuset i Sigtuna. I en artikel i Svenska Morgonbladet beskrivs patienternas förväntade reaktioner så här:

Man kan livligt föreställa sig, att en patient som tillbringat de senaste åren i Belsen eller något annat koncentrationsläger bör, om sjukdomen ej avtrubbat reaktionsförmågan, känna sig ha kommit bra nära himlen, när han eller hon lägges $\mathrm{i}$ någon av de vackra salarna eller elevhemmen, med utsikt över grönskande backar och Mälaren i sommarsol. Rad i rad står de fint bäddade sängarna med nytvättade lakan. ${ }^{26}$

En viktig del i dessa beskrivningar är att flyktingarna får tillgång till sådana produkter som säkerligen en stor del av tidningarnas läsekrets inte har sett sedan före krigsutbrottet. En artikel i Aftonbladet som beskriver förberedelserna inför flyktingarnas ankomst har rubriken "Dunkudde och förkrigslakan väntar de sjuka f.d. fångarna». Beredskapssjukhuset beskrivs i det närmaste som en lyxig kuranstalt:

Varenda säng är bäddad, när vi går ronden idag, och vilka sängar! Förkrigsmaterial från början till slut - dunkuddar och goda madrasser, lakan, ofta av bästa linne, och fina filtar. Flanellrockar av numera åtrådd kvalitet ingår också i utrustningen för konvalescentpromenader i pergolan av vildvin och rosor. ${ }^{27}$

Några dagar senare har även Upsala Nya Tidning en artikel om hur de första flyktingarna anländer för att »rekreera sig i mälarstaden» och "få vård i härlig miljö». ${ }^{28}$

Något som är slående är att flyktingarna inte har någon som helst kontakt med lokalbefolkningen i Sigtuna, förutom sådana som arbetar på sjukhuset. Staden Sigtuna utmålas som en plats vars "gästfrihet är världsberömd», men denna gästfrihet går ut på att man ska upplåta sina institutioner till beredskapssjukhus, inte att man ska ha personliga kontakter med flyktingarna. Tvärtom, på grund av 
karantänen uppmanas också i början allmänheten uttryckligen att hålla sig borta. ${ }^{29}$ Lokaltidningen Sigtunabygden konstaterar också att någon möjlighet att ha kulturellt utbyte med flyktingarna inte fanns på grund av språkbarriären. ${ }^{30} \mathrm{I}$ skenet av detta är det intressant att i en artikel som samma tidning publicerade 50 år senare så betonade istället en av de sköterskor som hade arbetat där att det inte hade varit något problem att kommunicera med flyktingarna: "De flesta talade ju tyska, och det lärde man sig i skolan på den tiden. $\aleph^{31}$ Denna bild av flyktingarna som kommande från en främmande kultur ges även i en av de tidigaste artiklarna som beskriver flyktingarnas ankomst där skribenten beskriver de nyanlända på detta sätt: „De sjöng sina vemodiga och glada men alltigenom obegripliga sånger ${ }^{32}$

Däremot betonar flera av artiklarna att staden Sigtuna i betydelsen dess natur och de vackra omgivningarna ska bidra till att läka flyktingarnas kroppar och själar. Dagens Nyheter skriver i en artikel om förberedelserna inför flyktingarnas ankomst:

Det bör bli en strålande upplevelse och kontrast för de krigshärjade människorna att få sitta här bland rosenbuskarna och njuta friden och stillheten i det sköna Sigtuna.[...]Allting går som smort. Lasaretten är snart färdiga, och den underbaraste blomsterprakt lyser och doftar utanför fönster och dörrar. Sigtuna bör vara stormförtjust att få ställa denna oskattbara oas till krigsoffrens förfogande. ${ }^{33}$

Sigtunastiftelsens rosengård beskrivs också som »världens vackraste sjukhusloggia». ${ }^{34}$ Den naturromantiska tendensen håller i sig i beskrivningarna av Sigtunasjukhuset. Vestmanlands Läns Tidnings reporter beskriver vid ett besök i oktober de kvarvarande patienterna så här: „Glada såsom barn sitta de där i solskenet eller vandra omkring i pelargångarna och njuta av suset från tallarna och utsikten över Mälaren och skogarna därbortom.»

Ibland kontrasteras också de fasor som patienterna har upplevt med deras nuvarande vistelse i det vackra Sigtuna. Lokaltidningen Sigtunabygden beskriver hur Sigtuna inte längre bör kallas "Ungdomsskolornas stad» utan snarare "De sjukas stad", men betonar ändå vilken dramatisk förändring ankomsten till Sigtuna måste utgöra för flyktingarna: 
Från dödslägret i Belsen har en liten procent av överlevande, utpinade, utmärglade människor, vilka dödsmaskinerna ej fick tid att avliva, kommit, för att genom svensk samaritgärning återfå fysisk och om möjligt psykisk hälsa. En del av dessa har kommit till oss i Sigtuna. Även däri ser vi en stor uppgift för vår stad med dess rika möjligheter både när det gäller lämpliga lokaliteter och en underbar rogivande natur. ${ }^{35}$

\section{Hur beskrivs patienterna?}

Vilken bild får man då av de flyktingar som kom till Sigtuna? Om vi för ett ögonblick bortser från artikelmaterialet och istället ser till den information man får om dessa människor från deras sjukjournaler, så hade de alla dramatiska levnadsöden. På korten har läkaren ofta antecknat patientens tidigare yrke: husmor, sekreterare, läkare och vad patienten har upplevt under krigsåren. Fördes till ghettot i Warszawa. Tillfångatogs under upproret i Warszawa. Koncentrationsläger Auschwitz, Dachau, Bergen-Belsen. Engelska sjukhuset. Därtill uppgifter om saknade anhöriga: barn, makar, föräldrar. Varje levnadsöde känns som en roman, och ur ett modernt journalistiskt perspektiv skulle man kunna tycka att den journalist som hade fått möjlighet att intervjua några av flyktingarna om deras personliga historier skulle ha kunnat ge en mycket levande skildring av krigets fasor ur ett inifrånperspektiv. Men dessa berättelser lyser helt med sin frånvaro i det samtida pressmaterialet. Generellt kan man säga att bilden av flyktingarna tecknas i vaga konturer, och det dröjer länge innan enskilda individer stiger fram.

Låt oss uppehålla oss ett ögonblick vid hur flyktingarna benämns. Här finns det ingen konsekvent terminologi utan olika artikelförfattare använder olika uttryck: »sjuka flyktingar», ${ }^{36}$ »befriade fångar», "patienter», ${ }^{37}$ "f.d. tyska krigsfångar», ${ }^{38}$ "de krigshärjade människorna», ${ }^{39}$ "de tyska nazisternas offer», "utlänningarna», »sjuklingar från utlandet», ${ }^{40}$ "f.d. koncentrationslägerfångar», "f.d. tyskfångar», ${ }^{41}$ "judinnorna». ${ }^{42}$ Det är dock påtagligt att artiklarna så sällan nämner att en majoritet av patienterna är judar, något som däremot ofta nogsamt antecknas i deras sjukjournaler. ${ }^{43}$

I de tidigaste artiklarna beskrivs flyktingarna nästan alltid som 
grupp, aldrig som individer. Det är också slående att det dröjer en dryg månad innan någon av flyktingarna förekommer på bild med sitt namn angivet. ${ }^{44}$ En illustration av hur flyktingarna generellt framställs som grupp medan representanter för den svenska vårdpersonalen kan stiga fram som individer är en bild som publicerades i Morgontidningen den 3 juli. Bilden visar sex unga kvinnor som ser ut genom ett fönster och en äldre sköterska i uniform som står utanför fönstret. Bildtexten lyder: „Syster Aina från Sundsvall håller ett öga på en samling unga kvinnor från Tjeckoslovakiet [sic!], som tittat ut ur ett fönster på Sigtunaskolan.» Syster Aina från Sundsvall är en individ, de unga patienterna är en namnlös grupp.

I vissa artiklar framgår det att flyktingarna är mycket sjuka och medtagna. ${ }^{45}$ Dessa beskrivningar övergår dock snart i rapporter om att deras tillstånd var bättre än förväntat, och att de snabbt repar sig när de kommit till Sigtuna. ${ }^{46}$ Detta står i skarp kontrast till två artiklar som publicerades femtio år senare, 1995, i lokaltidningen Sigtunabygden där en av de patienter som togs emot på sjukhuset och en av de sköterskor som arbetade där beskriver hur många av patienterna som dog under sin vistelse på Sigtunasjukhuset. Sköterskan Britt Nyqvist säger: "Som jag minns det dog någon nästan varje dag.» ${ }^{47}$

Det är svårt att avgöra på basis av sjukjournalerna exakt hur många av sjukhusets patienter som dog under sin tid i Sigtuna. Om man räknar samman de fall där det uttryckligen står att patienten har avlidit, så blir det $\mathrm{I} 7$ personer under de första tre månaderna. Det finns dock ett stort antal journaler som bara upphör, utan angivelse om det beror på att patienten har avlidit, skrivits ut eller flyttats till annan institution. Icke desto mindre visar detta på ett område där de medicinska journalerna skiljer sig från pressmaterialet där döden är påtagligt frånvarande och bara omnämns i vaga ordalag. ${ }^{48}$ Detta blir extra tydligt när man läser vissa av artiklarna som ger en mycket solig bild, och sedan jämför dessa med de medicinska journalerna. Den 6 augusti publicerar Aftontidningen en artikel med rubriken "Sömnad, språkövning och svenskt bröd bästa botemedlet för f.d. fångflickor». Artikeln är käck som en pilsnerfilm och handlar om hur händiga, arbetsamma och driftiga de tillfrisknande patienterna är, vilken glupande aptit de har, hur "rosiga, runda och frimodiga» de har blivit. Sjukjournalerna däremot visar att samma vecka hade fyra patienter avlidit i tbc eller lungsäcksinflammation. Under de 
kommande dagarna skulle ytterligare fyra patienter avlida. Av dessa realiteter syns inget spår i artiklarna.

Döden lyser alltså med sin frånvaro i tidningarnas beskrivningar av flyktingarna. Istället betonas hur de repar sig och framför allt hur mycket de uppskattar sjukhusmaten och går upp i vikt. ${ }^{49}$ Att rekordet för viktuppgång var sex kilo på en vecka upprepas i flera artiklar. ${ }^{50}$ En av de få flyktingar som får träda fram med namn och bild är Elisabeth Klein som sedan hon återfått krafterna har startat en »sömnadsateljé» på sjukhuset. Hon får berätta att hon lagt ut I4 centimeter kring midjan efter en månad på Sigtunasjukhuset, men att »nu får det vara nog, tycker hon, tjockare vill hon inte bli». ${ }^{51}$

Ibland är det uppenbart att reportrarna inte har talat med någon av flyktingarna och det är svårt att befria sig från känslan av att en hel del av de hoppfulla tolkningar som återfinns i artiklarna främst ligger i betraktarens ögon, som till exempel när Svenska Dagbladets reporter skriver:

Men mer än de magra ansiktena minns den, som besökt sjukhusen i Sigtuna, dessa kvinnors leenden, som de riktade mot alla de mötte, mer än den ännu svaga och stapplande gången minns han ljuset och den nyväckta framtidstron som strålade ur deras ögon. ${ }^{52}$

Det förekommer också av och till att reportrarna har talat med personalen på sjukhuset och låter dem berätta hur patienterna ser på framtiden. Så säger till exempel chefsläkaren H. Malmros att patienterna är på bättringsvägen och "många av dem ser redan på livet med ljusare blick än när de anlände till Sverige, utmärglade och sjuka. [...] Det är roligt att se hur livsmodet återvänder och i allmänhet är de glada och nöjda, frånsett naturligtvis den oro, som pressar dem då det gäller deras anförvanter.» ${ }^{53}$

Artiklarna betonar också den stora tacksamhet flyktingarna känner mot sina välgörare. Så här beskriver Stockholmstidningens reporter, själv rörd till tårar av åsynen av flyktingarnas ankomst, reaktionerna på de kläder som de nyanlända flyktingarna fick ta emot sedan deras egna tagits ifrån dem vid ankomsten till Sverige: „De nya plagg som utdelades - söta nattlinnen och konstsilkestrumpor bl. a. - framkallade tårar i ögonen på många av obeskrivlig glädje och tacksamhet.» ${ }^{54}$ 


\section{Sjukhuspersonalen}

Om skildringarna av patienterna är vaga och opersonliga så är beskrivningarna av sjukhuspersonalen desto utförligare. De är vänliga, leende, hårt arbetande, tjänstvilliga och går in för sin uppgift med hänförelse. ${ }^{55}$ Aftonbladets reporter skriver om de bråda förberedelserna:

Stämningen är förväntansfull och glad. Man väntar sig mycket av den här vistelsen. Husmor berättar, att den, som eventuellt kände trötthet i början, måste bli uppfriskade som aldrig förr, hur lång arbetsdagen än är, tack vare dr Odéns entusiasm och arbetsförmåga. ${ }^{56}$

Överläkare Olof Odén förefaller ha varit en person som kunde entusiasmera inte bara sin personal utan även de utsända reportrarna. Ingen reporter ställer någonsin någon kritisk fråga till överläkaren utan snarare framställs han som en hedersman, som t. ex. i följande utvikning i en artikel som publicerades någon vecka före de första flyktingarnas ankomst:

Det är en sprudlande man, fylld av lust att på bästa sätt lösa sin uppgift. Han är en sådan karl som skrivaren trivs med. Han vet allt om sitt jobb. Han ger direkta, kunniga och intelligenta svar på alla frågor. Skulle nu skrivaren berätta allt som dr Odén förkunnade bleve det en hel tidning. ${ }^{57}$

Även när det gäller sjukhuspersonalen återkommer samma bild av att vistelsen i Sigtuna ska bli den totala motsatsen till flyktingarnas erfarenheter från koncentrationslägren.

I utövandet av vår samaritgärning skall dock säkerligen kontrasten mellan människokärleken och människoplågandet ge outplånliga intryck, för dessa människospillror att ta med sig när de återställda reser härifrån igen. ${ }^{58}$

Sjukhuspersonalen ägnar sig inte bara åt den medicinska vården av patienterna utan ombesörjer även allehanda förströelser och hjälper patienterna att ta de första stegen för att lokalisera sina släktingar. ${ }^{59}$ På samma sätt som när det gäller patienterna så tolkar skribenterna ibland stämningen på avdelningen och generaliserar om personalen utan att egentligen redovisa hur han eller hon har kommit till dessa slutsatser. Så skriver till exempel Vestmanlands Läns Tidnings repor- 
ter efter ett besök på sjukhuset i oktober, då redan en stor andel av flyktingarna hade flyttat därifrån:

Här finns allt: hypermodern röntgenutrustning, operationsrum, tandläkarmottagning och laboratorium, och vilket är lika viktigt som moderna tekniska resurser - en stab av skickliga och ansvarskännande läkare och sköterskor. Man har en bestämd känsla av att hela personalen, från köksbiträdena till överläkaren, är besjälad av en enda tanke: att göra allt för sina skyddslingar. ${ }^{60}$

En speciell kategori bland personalen utgörs av en grupp frälsningssoldater som omnämns i två av de senare artiklarna. En artikel från den I oktober nämner att Frälsningsarmén har nio »efterkrigshjälpare» placerade vid sjukhuset. ${ }^{61}$ De uppvaktar patienterna på deras födelsedagar och varje kväll sjunger de ur Frälsningsarméns sånghäften med patienterna. ${ }^{62}$ Det är intressant att detta inte upplevs som problematisk, särskilt som samma artikel vet att berätta om patienterna att »de flesta är strängt ortodoxa, varje fredagskväll tänder de sitt lilla röda ljus, och på lördagen får allt arbete vila - inte ens fotografering vill de tillåta.»

Frälsningssoldaternas närvaro framhävs snarare som något som sprider glädje på sjukhuset: "Men eljest är den glada och hoppfulla stämningen omisskännlig, det vilar tydligen inga ledsamheter där salvationisterna, den glada kristendomens representanter drar fram.» ${ }^{63}$

Samtidigt finns det också en och annan rapport som går emot denna alltigenom positiva och idealistiska bild av vårdpersonalen. Aftonbladets beskrivning av personalens förväntansfulla inställning modereras i samma artikel av kommentaren »Lönen är dock, särskilt bland samariterna, så pass bra, att det är onödigt att generalisera och påstå, att det endast skulle vara det rent humanitära som lockat över lag.»" ${ }^{64}$ En artikel tre veckor efter de första flyktingarnas ankomst talar om en skriande brist på personal på sjukhuset, något som skribenten verkar tycka är upprörande:

Nog bör det finnas ett par hundra lämpliga flickor, som är villiga att åta sig detta arbete för längre eller kortare tid. Då Sverige tagit på sig denna uppgift och berett de sjuka en fristad i vårt land, är det också för oss en hederssak att uppgiften 
klaras på bästa möjliga sätt och att de sjuka gästerna får den vård och den skötsel, som de efter sina genomgångna lidanden så väl behöver. ${ }^{65}$

\section{Skildringen av beredskapsjukhuset - en sammanfattuing}

Hur kan man då sammanfatta generella drag i den bild som svensk press gav av mottagandet av före detta koncentrationslägerfångar i Sigtuna?

- Inför flyktingarnas ankomst fanns det farhågor i bygden, dels för att de skulle föra med sig en risk för smittosamma sjukdomar, dels för att de fyra skolor där beredskapssjukhuset inhystes inte skulle kunna starta sina ordinarie kurser till hösten. Dessa farhågor balanserades dock med uttalanden om att Sverige, som krigsskonat land, hade ett ansvar att göra vad man kunde för flyktingarna.

- Beredskapssjukhuset i Sigtuna skildras som rena paradiset. Inte minst de natursköna omgivningarna förväntas ha en läkande effekt på patienterna. Däremot har patienterna inga kontakter med lokalbefolkningen.

- Flyktingarna skildras i huvudsak som grupp, inte som individer. Artiklarna berättar mycket lite om deras bakgrund. Istället koncentreras skildringarna till att beskriva deras tillfrisknande, hur de ökar i vikt och hur deras livsmod återvänder. Att många av flyktingarna var så sjuka och medtagna att de avled under sin vistelse i Sigtuna framgår inte, och när dödsfall omnämns är det i vaga ordalag.

- Vårdpersonalen däremot skildras tämligen utförligt och i mycket positiva ordalag. De är flitiga, vänliga och tjänstvilliga. Särskilt husmor Svea Kruse och överläkare Olof Odén förekommer ofta i artiklarna.

Man kan alltså dra slutsatsen att dessa artiklar egentligen handlar mer om Sverige och de svenskar som deltar i arbetet på sjukhuset än om de flyktingar som kom hit. Ibland ger också ordvalet i artiklarna intrycket av att flyktingarna själva bara är ett instrument för att Sverige och svenskarna ska få möjlighet att göra en humanitär insats, som till exempel när Upsala Nya Tidning beskriver de väntade flyktingarna som »en större kontingent befriade krigsfångar såsom ett led i vårt lands humanitära efterkrigshjälp». ${ }^{66}$ Sveriges och svenskarnas insats 
är ett tema som återkommer ett flertal gånger i artiklarna. Chefsläkaren H. Malmros kallas »Belsenfångarnas välgörare». ${ }^{67} \mathrm{Hälften}$ av de flickor som hade sökt till Sigtunastiftelsens sommarkurs anmälde sig istället till frivillig tjänst på beredskapssjukhuset eftersom "alla ville vara med och tjäna i ordets egentliga bemärkelse.» ${ }^{68}$ Sverige erbjuder de sjuka »en fristad» och det är »en hederssak att uppgiften klaras på bästa möjliga sätt». ${ }^{69}$ Beredskapssjukhuset och mottagandet av flyktingar där kallas »en samaritgärning». ${ }^{70}$

\section{Analys}

Hur kan man förstå dessa artiklars skildring av beredskapssjukhuset i Sigtuna mot bakgrund av tidigare forskning om invandrare och flyktingar i media? Ylva Brune har i sin avhandling Nyheter fran gränsen studerat hur moderna svenska medier skildrar invandrare och flyktingar. En viktig förförståelse för Brune, som jag även tror är avgörande för förståelsen av artiklarna som denna studie är baserad på, är att nyheter inte bara är avtryck av verkligheten utan de är skapade produkter som har fått en viss form. Dessutom, hävdar jag med Brune, att nyhetsrapporteringen inte bara speglar samhället utan i själva verket är med och konstruerar det. ${ }^{71}$

Ett viktigt tema i Brunes bok är hur nyhetsmedierna upprättar eller befäster gränser mellan Sverige och flyktingar och hur idéer om det goda samhället formuleras samtidigt som medierna beskriver det som de konstruerar som främmande. ${ }^{72}$ När nyhetsjournalister rapporterar om händelser i Sverige och omvärlden så deltar de samtidigt $\mathrm{i}$ ett kulturellt och nationellt identitetsskapande. ${ }^{73}$ Texterna uttrycker föreställningar om vilka »vi» är, dvs den enhet som utgörs av reportrarna, den föreställda läsekretsen och de personer i texterna som dessa identifierar sig med. Detta görs bland annat genom att upprätta gränser mot de personer som inte upplevs ingå i detta "vi». ${ }^{74}$ Konstruktionen av ett "vi» och ett "de» kan ske genom att en serie skillnader mellan dessa två grupper framhävs, till exempel genom en asymmetrisk relation: „vi ger dem hjälp». Den typen av texter behöver inte nödvändigtvis framställa »dem» på ett negativt sätt, utan kan snarare beskrivas som en grupp som är objekt för "våra» åtgärder och därmed för "vår» empati och välvilja. ${ }^{75}$

Hur kan vi förstå texterna om Sigtunamottagandet mot bakgrund 
av Brunes analysmodell? Det är tydligt att det »vi» som genomsyrar texterna utgörs av svenskarna som agerar i texterna samt den svenska läsekretsen som ibland tilltalas direkt av skribenter eller myndighetspersoner som i artiklarna får förklara vikten av att Sverige göra denna insats. Kanske kan man inkludera hela nationen Sverige som kollektiv eller abstrakt entitet i detta "vi», och så även den svenska naturen. "De» utgörs följaktligen av flyktingarna som inte framställs som personer som ens i framtiden kan bli en del av detta svenska "vi». Vilka roller tilldelas då "vi» och »de» i dessa artiklar?

"Vi», dvs. svenskarna är aktiva, agerande, vänliga, leende, generösa och kompetenta. Artiklarna utgör ett exempel på det Brune beskriver som en vanlig teknik för att skapa gränder mellan »oss» och "dem», nämligen att man betonar en asymmetrisk relation. "Vi» gör en barmhärtighetsgärning mot »dem». "Vår» uppgift är att ta hand om och bota dem. Sedan ska »de» åka härifrån och allt ska återgå till det normala.

"De» har två huvudsakliga funktioner i texterna:

- Att uttrycka tacksamhet för den samaritgärning och vänlighet "vi» har visat "dem».

- Att vara objekt för "vår» omsorg och barmhärtighet och visa på dess effektivitet genom att så snabbt som möjligt tillfriskna. I skenet av denna analys blir den fokusering på tillfrisknande och viktökning som vi har funnit i materialet logisk. Logiskt blir också att flyktingarna i dessa artiklar varken har något förflutet eller någon framtid eftersom deras roll i artiklarna inte är som subjekt utan som objekt för "vår» välvilja. Det förklarar också den undanskymda roll som döden spelar i detta material. Att många av flyktingarna avled under sin vistelse i Sverige stämmer dåligt överens med deras funktion i dessa texter. Sverige skulle framställas som livets land i motsatsen till det dödens land som de kom ifrån.

Hur kan man relatera det som framkommit om pressens skildring av beredskapssjukhuset i Sigtuna till tidigare forskning om attityder till flyktingar i Sverige under krigs- och efterkrigstiden? Mikael Byström har i sin avhandling En broder, gäst och parasit studerat dels artiklar från svenska nyhetsmedier, dels riksdagsprotokoll. Hans studie bekräftar tidigare studier som har visat att en förändring ägde rum i den svenska flyktingpolitiken omkring 1942 så att den tidigare restriktiva politiken blev mer generös. I94I fanns det cirka 2I 500 
flyktingar registrerade i Sverige. Vid krigets slut, i april I945, hade den siffran stigit till I85 000. ${ }^{76}$

Byström menar att en viktig drivkraft i den svenska flyktingmottagningen under krigets sista år och efterkrigstiden var det han kallar "jakten på goodwill». Genom en aktiv hjälpverksamhet skulle Sverige kunna tvätta bort det tveksamma rykte som landet hade skaffat sig genom sin neutrala ställning under kriget. Byström menar dock att den dominerande delen av debatten hävdade att dessa humanitära insatser i första hand skulle utsträckas mot nordbor. ${ }^{77}$ Det är alltså tydligt att flyktingpolitiken var en del av utrikespolitiken och som sådan påverkade Sveriges relationer till andra länder. ${ }^{78}$ Beredskapssjukhuset i Sigtuna skulle kunna förstås i detta sammanhang, eftersom det var ett svar på en förfrågan från de allierades flyktingorgan UNRRA.

Dessutom har Byström visat att det fanns en utbredd tanke på att Sverige av tradition var ett humanitärt land. I debatter om flyktingpolitik hävdades det att ett utpräglat humanitärt åskådningssätt och ansvarstagande var karaktäriserande för svenskheten. ${ }^{79}$ Denna bakgrund i den svenska politiska debatten under krigets sista år och efterkrigstiden verkar stämma väl överens med de upprepade referenserna till Sveriges barmhärtighetsgärning och samarittjänst i det att Sigtuna och Sverige tagit sig an dessa stackars »sjuklingar». Till detta kopplas upprepade påpekanden om att Sverige varit förskonat från kriget. Hur ska man tolka denna koppling? Ska diskursen om den svenska humanitära traditionen och barmhärtigheten också kopplas till en sorts överlevarskuld: eftersom Sverige skonats måste vi nu betala priset i form av omsorg med dem som drabbats?

Byström konstaterar också att det var mycket ovanligt att flyktingar namngavs i svensk press och att detta dessutom stred mot Informationsstyrelsens rekommendationer. ${ }^{80}$ Även detta verkar stämma med materialet från Sigtunasjukhuset, men då ska man ändå konstatera att när dessa artiklar skrevs var kriget över och pressen kunde rapportera fritt, men kanske satt krigsårens restriktioner ännu kvar i ryggmärgen, vilken också kan ha påverkat artiklarnas utformning.

Byström beskriver hur negativa stereotyper om flyktingar som kriminella, våldsamma, osedliga och berusade cirkulerade i pressen under krigsåren och efterkrigstiden. ${ }^{81}$ Något sådant finns överhuvudtaget inte i Sigtunamaterialet, möjligen beroende på att 
majoriteten av flyktingarna som kom till Sigtuna var unga kvinnor. Byström visar dock att det fanns ett ämne där den svenska pressen uttryckte en odelad beundran och det gäller olika typer av kulturella arrangemang, t. ex. teaterföreställningar, sångaftnar och slöjdverksamhet. Byström skriver: »I de här sammanhangen framställs flyktingarna som en kreativ och tappert kämpande grupp som försökte hålla modet uppe i väntan på att få återvända till sina hemländer.» ${ }^{82}$ Antagligen ska man ordna in de artiklar som handlar om Sigtunapatienternas handarbetsskicklighet och flit i denna tendens.

Hur kommer det sig då att reportrarna väljer att inte skriva om Sigtunapatienternas upplevelser i koncentrationsläger? Kan man tänka sig att det fanns orsaker i journalisternas arbetssituation som skulle kunna förklara detta?

Under kriget utgick upprepade påbud från regeringen, utrikesdepartementet och Statens informationsstyrelse som uppmanade svenska massmedier att vara återhållsamma med att rapportera sådana utrikesnyheter som skulle kunna leda till försämrade relationer med någon utländsk stat. ${ }^{83} \mathrm{I}$ detta syfte skapades också pressnämnden med ledamöter från pressens egna organisation och de större dagstidningarna och som skulle fungera som ett frivilligt kontrollorgan som skulle se till att medierna inte gick över gränsen för vad som ansågs acceptabelt. ${ }^{84}$ Pressnämnden gav också ut "redaktionella anvisningar» som skulle fungera som riktlinjer för hur medierna skulle rapportera. I april 1942 utfärdade pressnämnden ett tillägg till sina anvisningar med följande ordalydelse:

Detaljerade skildringar av grymheter i samband med kriget böra undvikas, från vilket håll de än komma. Samtliga krigförande äga rikt material av sådant slag, och våra förbindelser med främmande makter skulle kunna allvarligt störas, om svensk press gjorde sig till ett fält för grymhetspropaganda. Sanningshalten av dylika uppgifter är dessutom svår att kontrollera. ${ }^{85}$

Det fanns dock en tydlig tendens i inskränkningen av pressfriheten. När tidningar blev konfiskerade eller belades med transportförbud (förbud att transportera tidningar och böcker som ansågs äventyra Sveriges säkerhet) så var det i övervägande delen av fallen tidningar på vänsterkanten som kritiserade Tyskland och dess allierade. ${ }^{86}$ 
Pressnämnden ville alltså inte att svenska journalister skulle skriva om grymheter som begåtts under kriget. Ett annat återkommande ämne för uppmaningar från pressnämnden var att svenska medier inte skulle skriva om flyktingar. Ibland motiveras detta med att flyktingar givits utresetillstånd till Sverige under förutsättning att saken inte fick någon publicitet i Sverige. Andra gånger är motiveringen för detta förbud oklar. ${ }^{87}$

Pressnämnden fick dock redan från början kritik från journalistkåren. ${ }^{88}$ När Tysklands krigslycka vände 1943 upphörde också den tyska legationen med sina påtryckningar angående svenska mediers skildringar av kriget, trots att svenska tidningar just vid den tiden började bli mer frimodiga i sin rapportering. ${ }^{89}$ Samtidigt avtog också pressnämndens verksamhet tills den slutligen avskaffades $1944 .^{90}$

Kanske fanns det en kvarleva från de restriktioner som hade gällt under kriget i det faktum att så lite skrivs om de fasor Sigtunapatienterna hade fått genomleva. Samtidigt ska man veta att svenska medier alltsedan 1942 återkommande hade rapporterat om Förintelsen av de europeiska judarna. ${ }^{91}$ Med de allierades befrielse av fångarna i en rad koncentrationsläger i april I945 så spreds fotografier, berättelser och journalfilmer om koncentrationslägren över världen, även så i Sverige. Fotografierna från Buchenwald och Bergen-Belsen kom att forma synen på Förintelsen. ${ }^{92}$ Eftersom det var just Bergen-Belsen som flyktingarna i Sigtuna kom ifrån så finns det alltså anledning att tro att större delen av de svenska läsarna kunde föreställa sig vad flyktingarna hade bakom sig. Tidigare forskning har dock visat att intresset för koncentrationslägren och Förintelsen blev mycket kortvarigt. Det kulminerade under april-maj 1945, och redan i juni visar den svenska pressen mycket mindre intresse för att återge de överlevandes berättelser. ${ }^{93}$ Kanske ska man tolka frånvaron av berättelser om erfarenheterna från koncentrationslägren i skildringen av flyktingmottagningen i Sigtuna som en del i denna trend.

Tidigare forskning har också visat att det inte framgick av den svenska pressens skildring av koncentrationslägren att det var judar som hade utgjort majoriteten av offren. Tidningarna kallade offren oftast för "fångar» eller "polacker». ${ }^{94}$ Även detta stämmer väl överens med den tendens som kan ses i skildringarna av flyktingarna som kom till Sigtuna. Att de flesta var judar nämns bara i förbigående, om alls. Deras religiösa övertygelse och praxis diskuteras egentligen 
först i en av de sista artiklarna som sammanfaller i tid med de stora judiska högtiderna på hösten. ${ }^{95}$

Dessutom ska man nog koppla samman frånvaron av koncentrationslägerskildringar med den roll flyktingarna hade tilldelats i den bild som svensk press gav av detta mottagande. Deras roll var att tillfriskna och få nytt mod, inte att vittna om lidande. Krigstidens fasor passade inte heller in i den soliga bild av det idylliska Sigtunasjukhuset med dess leende sköterskor och läkande natur som dominerar artiklarna. Detta kan också förklara varför det dröjer en månad innan en av flyktingarna förekommer med både namn och bild, och att det då är en ung kvinna som under denna månad säger sig ha lagt ut 44 centimeter runt midjan. Flyktingarna i dessa artiklar stiger inte fram som representanter för dödslägren utan snarare som levande bevis för den svenska humanitära traditionen och barmhärtigheten. Då passar det bättre med "rosiga, runda och frimodiga» unga kvinnor än utmärglade koncentrationslägerfångar.

\section{En berättelse om Sverige och svenskarna}

Sammanfattningsvis kan man alltså konstatera att detta pressmaterial egentligen främst handlar om Sverige och svenskarna. En analys av framställningen av patienterna visar att dessa i den svenska pressens skildring bara fungerar som objekt för den svenska humanitära insatsen. Deras främsta funktioner är att uttrycka tacksamhet och att tillfriskna för att därmed vara levande bevis på den goda svenska vård som de kommit i åtnjutande av. Det som inte passar in i denna dramaturgi, till exempel det faktum att många av flyktingarna inte överlevde mer än en kort tid i Sverige, nämns knappast i artiklarna. Vad de har upplevt under kriget och vad de har för planer för framtiden är inte heller något som ges något större utrymme i artiklarna.

I dessa artiklar så skapar reportrarna ett "vi» som utgörs av dem själva, vårdpersonalen och läsarna. „Vi» beskrivs som aktiva, hårt arbetande, skickliga och vänliga. Detta "vi» kan dels skildras som en grupp som alla besjälas av samma ideal eller som individer som stiger fram med namn och ibland bild. Alla som ingick i detta "vi» kunde känna sig som bärare av den stolta, svenska humanitära traditionen genom att "vi» tog hand om »dem», dvs koncentrationslägerflyktingarna. Flyktingarna utgör det »de» mot vilket bilden av »oss» 
målas. »De» framställs som en grupp snarare än individer, och som främmande, hjälpbehövande men tacksamma.

\section{Noter}

${ }^{1} \mathrm{SvD} 450610$.

${ }^{2}$ Den här artikeln möjliggjordes genom ett forskningsstipendium från Harald och Louise Ekmans forskningsstiftelse vars stöd härigenom tacksamt erkännes.

${ }^{3}$ Se förteckning av använda artiklar i käll- och litteraturförteckningen under "Källor: Tryckt material».

${ }^{4}$ Kungl Medicinalstyrelsens arkiv, 1945 års flyktingsjukvård, sjukjournaler från Sigtuna beredskapssjukhus.

${ }^{5}$ Byström 2006.

${ }^{6}$ Brune 2004 .

${ }^{7}$ Byström 2006, s. 58.

${ }^{8}$ Byström 2006, s. II9. För en översikt över Sveriges förhållningssätt till judiska flyktingar under efterkrigstiden, se Samland 2004/2005.

${ }^{9}$ MT 450625

${ }^{10} \mathrm{AB} 450630$.

${ }^{11} \mathrm{AB} 450630$.

${ }^{12}$ Oron över detta speglas bl. a. i följande artiklar: DN 4506II, ST 4506I2, UNT 45062I, MT 450625 .

${ }^{13} \mathrm{AB} 450612$.

${ }^{14}$ UNT 450612.

${ }^{15} \mathrm{DN}_{450620 .}$

${ }^{16}$ ST 450730, SM 45roor.

${ }^{17} \mathrm{SB} 950301$

${ }^{18} \mathrm{AB}$ 450630, UNT 450702, SvD 450707.

${ }^{19} \mathrm{SM} 450630, \mathrm{MT} 450703$.

${ }^{20} \mathrm{MT}$ 450703, AT 450806, SM 451001.

${ }^{21}$ Med tanke på att beredskapssjukhuset ska byggas upp för befriade koncentrationslägerfångar, blir det nästan makabert att Dagens Nyheter en dryg vecka före flyktingarnas ankomst har en artikel med rubriken "Sigtuna blir storsjukhus. Hopp om att kunna frige stadens skolor i höst», 450620 (min kursivering).

${ }^{22} \mathrm{DN}_{4506 \mathrm{II}}$.

${ }^{23} \mathrm{ST} 4506 \mathrm{I} 2$.

${ }^{24} \mathrm{DN} 4506 \mathrm{II}, \mathrm{MT} 450625, \mathrm{SB} 450706$.

${ }^{25}$ MT 450625.

${ }^{26}$ SM 450630. Liknande beskrivning finns i UNT 450702 och i VLT 45I0IO.

${ }^{27} \mathrm{AB} 450630$. Liknande ordalag återfinns i SM 450630.

${ }^{28}$ UNT 450702.

${ }^{29} \mathrm{SM} 450630$.

${ }^{30} \mathrm{SB} 450706$. 
31 SB 95030I. Samma upplysning om patienternas kunskaper i tyska ges i en artikel från sommaren 1945 , SvD 450707.

32 ST 450702 .

${ }^{33} \mathrm{DN}_{450620 .}$

${ }^{34} \mathrm{SvD} 450630$.

35 SB 450706. Liknande användning av kontrast kan ses i MT 450703.

${ }^{36} \mathrm{SvD} 4506 \mathrm{IO}$.

${ }^{37} \mathrm{DN} 4506 \mathrm{II}$.

${ }^{38} \mathrm{AB} 4506 \mathrm{I} 2$.

${ }^{39} \mathrm{DN}_{450620 .}$

${ }^{40} \mathrm{MT} 450625$.

${ }^{41} \mathrm{MT} 450630$.

${ }^{42}$ MT 450703.

43 I MT 450503 omnämns flyktingarna som »judinnorna», i SvD 450707, nämns att "85 procent av de 2 Io kvinnorna äro judinnor", och i SM 45IOoI, beskrivs flyktingarna som ortodoxa judar, hur de håller sabbat, att de har fått besök av rabbinen på försoningsdagen och att har pyntat för lövhyddohögtiden. För mer om de judiska församlingarnas och organisationernas arbete bland flyktingar, se Hansson 2004.

${ }^{44}$ AT 450806.

${ }^{45}$ ST 450702

${ }^{46}$ UNT 450702, MT 450703 , SvD 450707.

${ }^{47} \mathrm{SB} 950524$ och 950301 .

48 T. ex. så säger husmor Svea i oktober om de patienter som då är kvar: „De flesta har tbc som svit av den omänskliga behandlingen i koncentrationslägren och inte ens den bästa vård har kunnat återbörda alla till livet.», SM 45IOOI. En dryg vecka senare skriver en reporter som bevittnat hur patienterna tillsammans med de frälsningssoldater som tjänstgjorde på sjukhuset sjungit en sång "om de kära som gått förut till himlens land. [...]Mina tankar gå till dem av gästerna, som det inte förunnades att få njuta så länge av vistelsen bland goda människor, till dem som vila i jorden i den 700-åriga Mariakyrkans hägn.», VLT 45IOIO.

${ }^{49} \mathrm{MT} 450703$, SvD 450707, SM 45IO0I.

${ }^{50} \mathrm{ST} 450730, \mathrm{AT} 450806$.

${ }^{51}$ AT 450806 .

$52 \mathrm{SvD} 450707$.

${ }^{53}$ ST 450730. Se även Svenska Morgonbladets intervju med husmor Svea Kruse som konstaterar att "de allra flesta har blomstrat upp fenomenalt fort och fătt nytt livsmod.», SM 45 IOOI.

${ }^{54}$ ST 450702. Se även AT 450806 och VLT 45 IoIO.

55 SM 450630 , UNT 450702.

${ }^{56} \mathrm{AB} 450630$.

${ }^{57} \mathrm{MT} 450625$.

58 SB 450706.

${ }^{59} \mathrm{SvD} 450707$.

${ }^{60}$ VLT 45 IOIO. 
${ }^{61} \mathrm{SM}_{45 \mathrm{IOOI}}$

${ }^{62} \mathrm{SM} 45$ Ioor. Se även VLT 45 IoIo.

${ }^{63} \mathrm{SM} 45 \mathrm{IOOI}$.

${ }^{64} \mathrm{AB} 450630$.

${ }^{65}$ ST 450722. En artikel i Aftontidningen ett par dagar senare berättar att det på grund av beredskapens avveckling finns gott om manliga sjukvårdare, men genom att större delen av patienterna på Sigtunasjukhuset är kvinnor så är det inte lämpligt att anställa dessa, AT 450726.

${ }^{66}$ UNT 45062I.

${ }^{67} \mathrm{ST} 450730$.

${ }^{68}$ VLT 45 IOIO.

${ }^{69} \mathrm{ST} 450722$

70 SB 450706.

${ }^{71}$ Brune 2005, s. I0, 25-26.

72 Brune 2004, s. 9.

73 Brune 2004, s. IO.

${ }^{74}$ Brune 2004, s. 34I.

${ }^{75}$ Brune 2004, s. 48-49.

76 Byström 2006, s. 2I.

${ }^{77}$ Byström 2006, s. 73, 75, 88-89.

${ }^{78}$ Byström 2006, s. 244.

${ }^{79}$ Byström 2006, s. 258.

${ }^{80}$ Byström 2006, s. 221.

${ }^{81}$ Byström 2006, s. 213-28.

82 Byström 2006, s. 237.

${ }^{83}$ Franzon I997, s. 67-68.

${ }^{84}$ Franzon 1997, s. 68-69, 7I.

${ }^{85}$ Franzon 1997, s. 82.

${ }^{86}$ Svanberg och Tydén 1997, s. 43-44.

${ }^{87}$ Andolf 1994, s. 34I-42.

${ }^{88}$ Franzon 1997, s. 85 ,

${ }^{89}$ Franzon 1997, s 86.

${ }^{90}$ Franzon 1997, s, 86, 88.

${ }^{91}$ Svanberg och Tydén 1997, s. 40-4I.

92 Svanberg och Tydén 1997, s. 383-385.

93 Svenberg och Tydén 1997, s. 390.

94 Svanberg och Tydén 1997, s. 388.

${ }^{95} \mathrm{SM} 45 \mathrm{IOOI}$. 


\section{Källor och litteratur}

\section{Källor}

\section{Otryckt material}

Riksarkivet, Marieberg, Stockholm:

Kungl Medicinalstyrelsens arkiv, 1945 års flyktingsjukvård, sjukjournaler från Sigtuna beredskapssjukhus, signum Fr:87-Fr:92a.

\section{Tryckt material}

Aftonbladet $(\mathrm{AB})$

450612, "Förberedelser för krigsfångar i Sigtuna»

450630, "Dunkudde och förkrigslakan väntar de sjuka f.d. fångarna”

450726, "Inga fler sjuka tyskar till Sigtuna»

Aftontidningen (AT)

450726, "Manliga sjukvårdare finns men önskas ej till f.d. tyskfångar»

450806, „Sömnad, språkövning och svenskt bröd bästa botemedlet för f.d. fång-

flickor"

Dagens Nyheter (DN)

4506II, "Befriade fångar i Sigtunaskolan. Drastisk åtgärd»

450620, "Sigtuna blir storsjukhus. Hopp om att kunna frige stadens skolor i höst»

Expressen (Exp)

450719, »Ingen risk för tarmtyfus vid Stockholmsbaden»

Morgontidningen (MT)

450625, »Flera sjuka i Sigtuna än på Södersjukhuset. Skolstaden var redo hysa

Stockholms sjuka vid krig»

450630, "Sigtunaskolornas bästa sjuksal var förut smedja»

450703, "Belsenfångarna nu i Sigtuna. Effektiv spärr»

Sigtunabygden (SB)

450706, "Sigtuna i samarittjänst»

450803, "Inga flera sjuklingar till Sigtuna?"

450810, "Sigtunasjukhusets avveckling"

95030I, "Otroligt att man kan förneka Förintelsen!»

950524, "Från skräcken till det idylliska Sigtuna»

Stockholmstidningen (ST)

450612, "Var det ofrånkomligt?»

450702, "'Man kunde röras till tårar att se de 222 Belsenkvinnorna'”

450718, "Prov från Blackanbadet förorenat: Risk för tyfussmitta - förbud i Sigtuna

att löga sig i Mälaren»

450722, "En hederssak för Sverige»

450730, »Dagens profil» (H. Malmros, chefsläkare)

Svenska Dagbladet (SvD)

450610, "Sigtuna får många sjuka flyktingar»

450630, "Sigtuna överträffar Södersjukhuset»

450707, "Belsenfångarna i Sigtuna äro glädjande pigga - hälften uppe»

Svenska Morgonbladet (SM)

450630, "Sigtuna berett mottaga I.200 sjuka utlänningar»

45IOOI, "Okuvlig vilja hos befriade Sigtunagästerna. Brev från anhöriga den bästa medicinen» 
Upsala Nya Tidning (UNT)

4506I2, »Myndigheterna lova största möjliga hänsyn till Sigtunas intressen» 45062I, "Sigtunaskolorna börja som vanligt i höst?»

450702, "De första flyktingarna installerade i Sigtuna»

Vestmanlands Läns Tidning (VLT) 45IOIO, »Femtonåriga Sigtunapatienter sutto 6 år i koncentrationsläger»

Örebrokuriren (ÖK)

45073I, "D:r Malmros om sin verksamhet bland Belsen-fångarna»

\section{Litteratur}

Andolf, Göran. 1994. "De grå lapparna. Regeringen och pressen under andra världskriget», Nya fronter. 1943 - spänd väntan, Bo Hugemark (red.), Stockholm, s. 304-349.

Brune, Ylva. 2004. Nyheter från gränsen. Tre studier i journalistik om »invandrare», flyktingar och rasistiskt våld, Göteborg.

Byström, Mikael. 2006. En broder, gäst och parasit. Uppfattningar och förestälnningar om utlänningar, flyktingar och flyktingpolitik i svensk offentlig debatt 1942-1947, Stockholm.

Franzon, Johan. 1997. „Pressnämnden 194I-1944. En svensk papperstiger?», Presshistorisk ärsbok, s. 66-90.

Hansson, Svante. 2004. Flykt och överlevnad. Flyktingverksamhet i Mosaiska församlingen i Stockholm 1933-1950, Stockholm.

Samland, Bjarnhild. 2004/2005. »Til det beste for Sverige? Svenske myndigheter og den Mosaiska församlingen i Stockholm sin politikk overfor jødiske displaced persons 1945 til 1950", Nordisk Judaistik 25.2, s. 103-132.

Svanberg, Ingvar och Mattias Tydén. 1997. Sverige och Förintelsen. Debatt och dokument om Europas judar 1933-1945, Stockholm. 